\title{
Cost-Benefit Analysis during Lockdown and Health Belief Model (HBM) of COVID-19 Pandemic in Ogun State, South-Western Nigeria
}

\author{
Oni, Olawale Bashir-Ud-Deen \\ Department of Public Health, Texila American University, Guyana, USA
}

\begin{abstract}
Due to unprecedented threat to the economy and the quality of life caused by the COVID-19 pandemic, this study focused on cost-benefit analysis during the lockdown of COVID-19 and the health belief model of COVID-19 pandemic in Ogun State, Nigeria. A total of 2400 copies of the questionnaire were administered to solicit information from the respondents using systematic random sampling technique on the targeted population while 2363 copies were retrieved and analyzed using descriptive statistics. The findings of the study revealed that the lockdown had negative impacts on health, economic, and social impacts. Results showed that $50.7 \%$ of the respondents spent no time going to the market and/or work during COVID-19, and this made $81.9 \%$ of them unable to gain extra gain during the lockdown as they were completely restricted for activities. The lockdown had impacts on socioeconomic activities as the prices of consumable goods increased due to the low supply. $71.8 \%$ of the respondents indicated that the government did not provide palliative measures for the households. The results further showed that everyone could be infected with COVID-19 as $86.0 \%$ of respondents indicated. $48 \%$ revealed that COVID-19 drugs were unavailable and prayers from religious leaders could not cure COVID-19. Besides, $65.5 \%$ were able to follow the basic measures put in place to reduce the spread of COVID-19 in the study area. This study concluded that necessary things should be put in place to ease the affairs of the populace before any other lockdown measure is made.
\end{abstract}

Keywords: Cost-Benefit, COVID-19, Health Beliefs, Nigeria.

\section{Introduction}

COVID-19, an acronym derived from "coronavirus disease 2019" by World Health Organisation (WHO) on February 11, 2020, has been declared and recognized as a global health emergency [1, 2], and a global pandemic [3]. These viruses are closely associated with infections such as pneumonia, the common cold, and conditions like severe acute respiratory syndrome (SARS) and Middle East Respiratory Syndrome (MERS). The most common ways the virus spreads from an infected person to healthy people is when they cough or sneeze and release viral particles into the air and through touching, shaking hands, and other forms of close personal contact [4].

To mitigate the spread of the COVID-19 pandemic, basic precautions were made, including the lockdown approach at many places in Nigeria and other parts of the world. The lockdown measure is highly restrictive on social freedoms and damaging to the economy.
Lockdown is described as the restriction of travels, closing of schools and nonessential businesses, banning social gatherings, and asking citizens to shelter in place [5]. Governments have had difficult choices to make on the best approach for their countries to contain the spread of COVID-19. No matter how wealthy a nation or country is, in the containment and mitigation of the global COVID-19 pandemic, it would eventually have a profound impact on the economy of the world, especially in low- and middle-income nations of the world. These measures may also affect the quality of life of many people in the world.

Furthermore, spiritualism has a significant impact on the health of individuals. Some religions, for example, dictate dietary laws and hygiene practices. It is unimaginable when an individual with a second degree level of education still creates ignorance of COVID-19 because he or she believes prayers work better than anything (e.g. Drugs) in control of the 
diseases. Such belief is completely odd and eventually results in complications such as sudden death, and total family disarray, and eventual greater economic loss. However, religious beliefs should not be a deterrence to medical care. Beliefs are described by [6] as a crucial link between socialization and behaviour; an enduring individual characteristic that shapes behaviour and can be acquired through primary socialization; and a modification that can differentiate between individuals from the same background.

The Health Belief Model (HBM) is recognized as the most widely applied, explanatory model in preventive health behaviour research [7, 8, 9]. Studies have shown that socioeconomic status, gender, ethnicity, and age which constitute demographic characteristics were known to be associated with preventive health-related behaviour patterns as well as differential use of health services [6]. Few studies have recently been conducted on the COVID-19 pandemic, but little or no studies have been conducted on cost-benefit analysis and the Health Belief Model of COVID-19 pandemic in Nigeria and any other part of the world. Therefore, this study focused on cost-benefit analysis during the lockdown and Health Belief Model (HBM) of COVID-19 pandemic in Ogun State, SouthWestern Nigeria. This is especially appropriate at this time in Nigeria because of its economic impact on the beliefs of people in the country.

\section{Health Belief Model}

The main characteristic of the Health Belief Model (HBM) is its emphasis on perception and motivation, thus reflecting the strong influence of Kurt Lewin's field theory [10, 11]. The model serves as a tool that scientists used to try and predict health behaviours. It was originally developed in the 1950s by psychologists Godfrey Hochbaum, Irwin Rosenstock and Stephen Regels working in the US Public Health Service [12, 13], and was updated in the 1980s [14].

The model is based on the theory that a person's willingness to change their health behaviours. The HBM suggests that a person's belief in a personal threat of an illness or disease together with a person's belief in the effectiveness of the recommended health behaviour or action will predict the likelihood the person will adopt the behaviour. According to the model, six primary variables influence a person's choice (Figure. 1). Four variables such as perceived susceptibility to ill-health (risk perception), perceived severity of ill-health (seriousness), perceived benefits of behaviour change (benefits), and barriers were included when the model was initially developed by [12, 15, 13]. It is indicated in Figure 1 that there were no clear guidelines on how to operationalize the links between perceived susceptibility, severity, and overall threat perception.

In general, the health belief model is a theoretical structure developed to explain why and under what conditions people will take preventive actions. In this study, the Health Belief Model (HBM) was used as the theoretical framework to identify and measure the level of concern for COVID-19 risk from religious faith and the reasons for not regularly engaging in preventive health behaviours. 


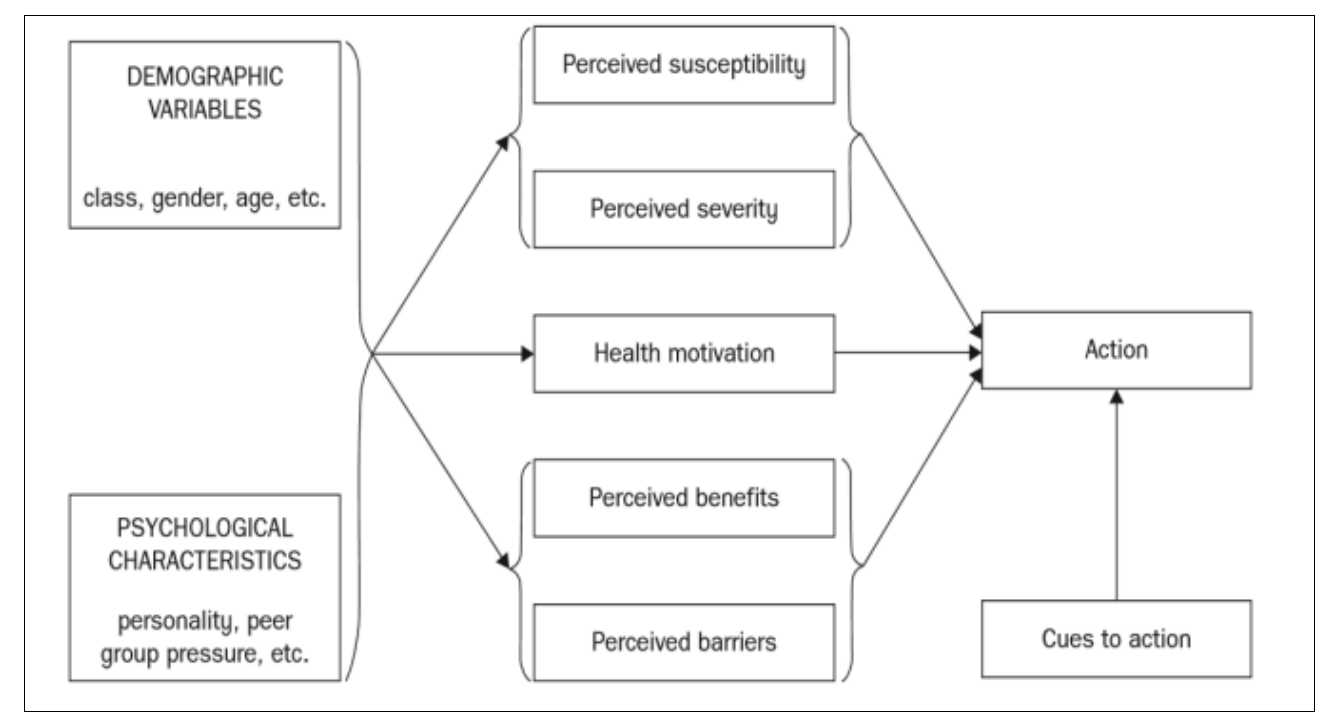

Figure 1. Health Belief Model

\section{Materials and Methods}

The study area was confined to Ogun State, Nigeria. Ogun State is one of the fastest developing states in the country. It lies in the southwestern part of the country between latitudes $6.2^{\circ} \mathrm{N}$ and $7.8^{\circ} \mathrm{N}$ of the equator, and longitudes $3.0^{\circ} \mathrm{E}$ and $5.0^{\circ}$ East of the Greenwich Meridian south (Figure. 2). Ogun State occupies an area of $16,980.55 \mathrm{~km}^{2}$, and a population of $3,751,140$, with a density of $220 / \mathrm{km}^{2}$ [16]. The State is bounded on the west by the Republic of Benin and the east by Ondo State. To the north is Oyo State, while Lagos State and the Atlantic Ocean are to the south. The geographical location of the State makes it accessible to the economically developed regions in Nigeria. Ogun State is made up of 20 Local Government Areas (Figure. 2).

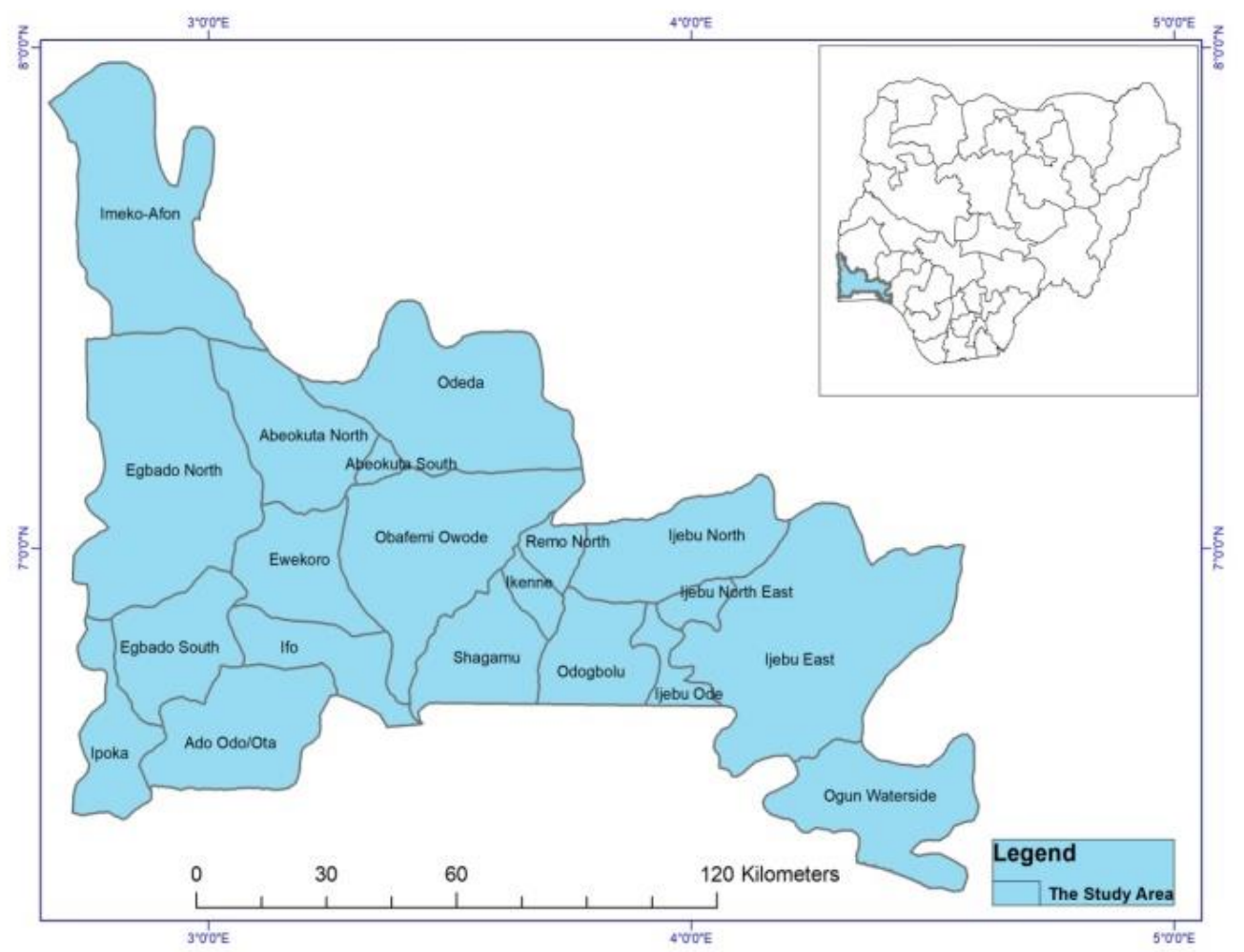

Figure 2. Ogun State, the Study Area 
Data used in this study were collected from primary sources. The primary source of data was collected through the use of a questionnaire. The target sample population was religious goers who were between the ages of 15 and above, and also the residents of the study area. The 2006 total population of the study area was 3, 751, 140 [16]. If the population growth rate would be the same as in the period 2006-2011 (3.36\%/year), the projected total population of the study area in the year 2020 will be 5, 954, 097 [17]. The ever increasing demand for research has created a need for an efficient method of determining the sample size needed to be representative of a given population. The determination of the sample size involves disregarding sampling error. For a sample to be accurate and errorfree, it must be optimum in size and representative enough. The sample size of 2400 was used based on the online sample size calculator by Raosoft, Inc. [18]. The sample size was calculated using the projected population $(5,954,097)$ for the year 2020 , with $2 \%$ margin of error, $95 \%$ confidence level, and $50 \%$ response distribution. A detailed and wellstructured questionnaire was designed and a total of 2400 copies of the questionnaire were administered using systematic random sampling techniques on the targeted population from all the 20 Local Government Areas of the State, who voluntarily walked in for services on Friday or Sunday. 2363 copies of the questionnaire were returned and analyzed using descriptive statistics. Statistical Package for Social Sciences (SPSS) version 23 was used for the analyses while the results were presented in frequencies tables, graphs, pie and bar charts, where applicable.

\section{Results}

\section{Socio-demographic Characteristics of the Respondents}

Table 1 and Figures $3-6$ present the demographic characteristics of the respondents in the study area. In table 1, 2299 (97.3\%) of respondents were Nigerians by nationality. Of all the total respondents considered in this study, $53.8 \%$ of respondents were male, while $46.2 \%$ were female. The majority of the respondents $72(30 \%)$ were between the ages 25 and 34 , while the least age group was $1.3 \%$ representing only 30 respondents between the ages of 75 and above in the study area. Of all the total respondents, $1090 \quad(46.1 \%)$ were married and a total of 1084 respondents representing $(45.9 \%)$ were single.

Only $2.5 \%$ of the total respondents did not have formal education, while the number of respondents with secondary and university education constituted larger percentages with $30.9 \%$ and $20.8 \%$ respectively. A very small number of the respondents which represents $0.3 \%$ belonged to none of the three major religions. A total of 1603 which represents $67.8 \%$ worshiped God since they were born, while only 24 respondents representing 1\% started worshipping God less than 5 years ago.

Figure. 3 shows that majority of the respondents which represent $80 \%$ of the sampled population were residents of Ogun State, the study area while others were $20 \%$ of the respondents were non-residents. Teachers and other professions constituted larger percentages of the respondents in the study area (Figure. 4). The percentages of respondents from different Local Government Areas in the study area were presented in Figure. 5. Figure. 6 shows that $2193(92.8 \%)$ were Yoruba, 103 (4.4\%) were Igbo, while Hausa constitutes 50 (2.1\%) of ethnic groups.

Table 1. Social-Demographic Characteristics

\begin{tabular}{|l|l|l|l|}
\hline Demographic Characteristics & Frequency & Percent (\%) \\
\hline \multirow{2}{*}{ Nationality } & Nigerian & 2299 & 97.3 \\
\cline { 2 - 4 } & Others & 64 & 2.7 \\
\hline \multirow{2}{*}{ Sex } & Male & 1271 & 53.8 \\
\cline { 2 - 4 } & Female & 1092 & 46.2 \\
\hline \multirow{2}{*}{ Age Bracket } & $15-24$ & 648 & 27.4 \\
\cline { 2 - 4 } & $25-34$ & 729 & 30.9 \\
\hline
\end{tabular}




\begin{tabular}{|c|c|c|c|}
\hline & $35-44$ & 471 & 19.9 \\
\hline & $45-54$ & 287 & 12.1 \\
\hline & $55-64$ & 156 & 6.6 \\
\hline & $65-74$ & 42 & 1.8 \\
\hline & $\begin{array}{l}75 \text { and } \\
\text { above }\end{array}$ & 30 & 1.3 \\
\hline \multirow[t]{6}{*}{ Marital Status } & Single & 1084 & 45.9 \\
\hline & Married & 1090 & 46.1 \\
\hline & Divorced & 62 & 2.6 \\
\hline & Separated & 47 & 2.0 \\
\hline & Widow & 38 & 1.6 \\
\hline & Widower & 42 & 1.8 \\
\hline \multirow[t]{7}{*}{$\begin{array}{l}\text { Level of } \\
\text { Education }\end{array}$} & $\begin{array}{l}\text { No Formal } \\
\text { Education }\end{array}$ & 60 & 2.5 \\
\hline & Primary & 108 & 4.6 \\
\hline & Secondary & 731 & 30.9 \\
\hline & $\begin{array}{l}\text { Col. of } \\
\text { Education }\end{array}$ & 262 & 11.1 \\
\hline & Polytechnic & 317 & 13.4 \\
\hline & University & 492 & 20.8 \\
\hline & $\begin{array}{l}\text { Post } \\
\text { Graduate }\end{array}$ & 393 & 16.6 \\
\hline \multirow[t]{4}{*}{ Religion } & Islam & 1388 & 58.7 \\
\hline & Christianity & 899 & 38.0 \\
\hline & Traditional & 69 & 2.9 \\
\hline & Others & 7 & .3 \\
\hline \multirow{5}{*}{$\begin{array}{l}\text { Years of } \\
\text { worshiping God }\end{array}$} & $<5$ years & 24 & 1.0 \\
\hline & $5-10$ years & 154 & 6.5 \\
\hline & $\begin{array}{l}11-20 \\
\text { years }\end{array}$ & 154 & 6.5 \\
\hline & $>20$ years & 428 & 18.1 \\
\hline & since birth & 1603 & 67.8 \\
\hline
\end{tabular}

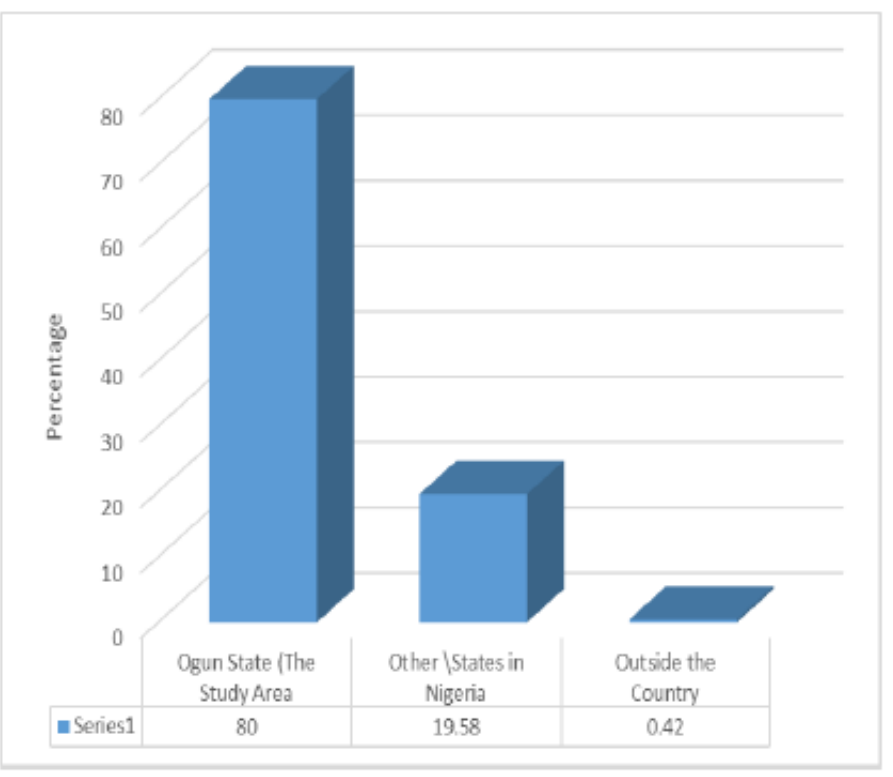

Figure 3. State of Residence 


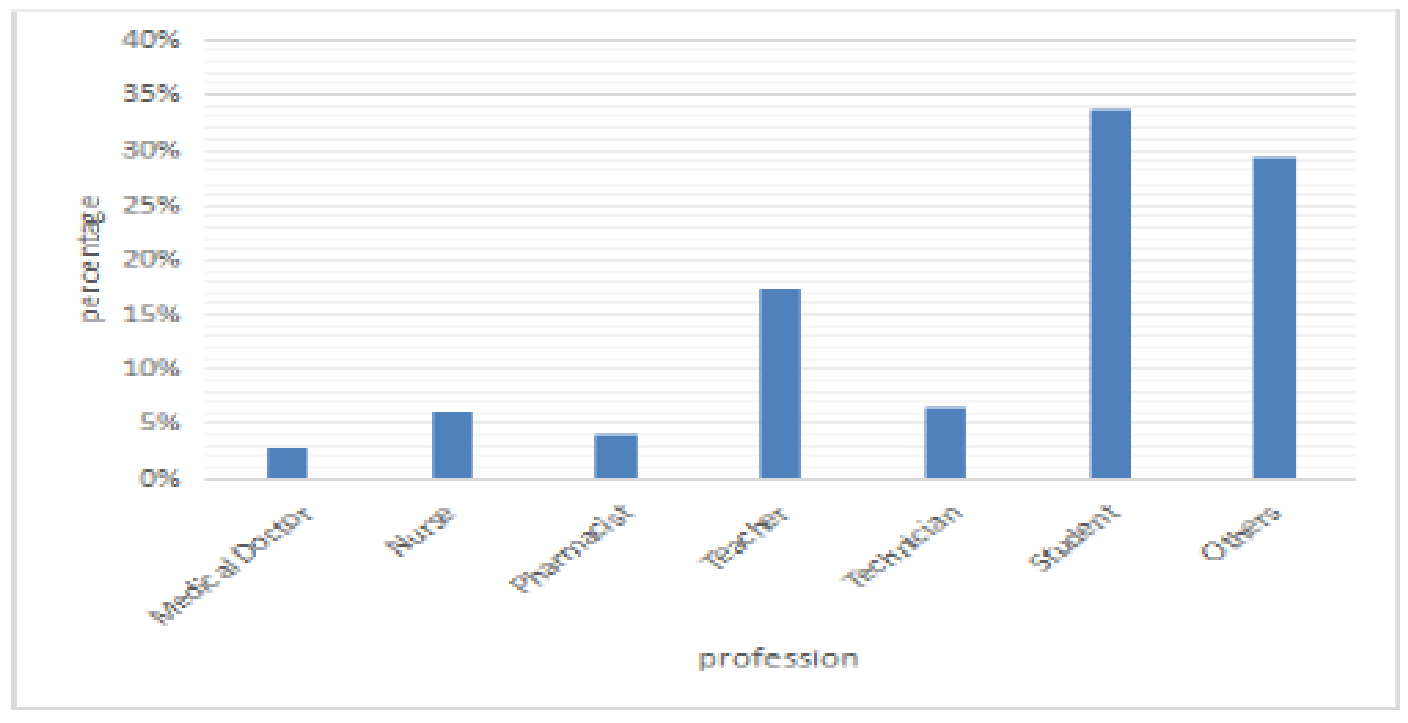

Figure 4. The Profession of Respondents in the Study

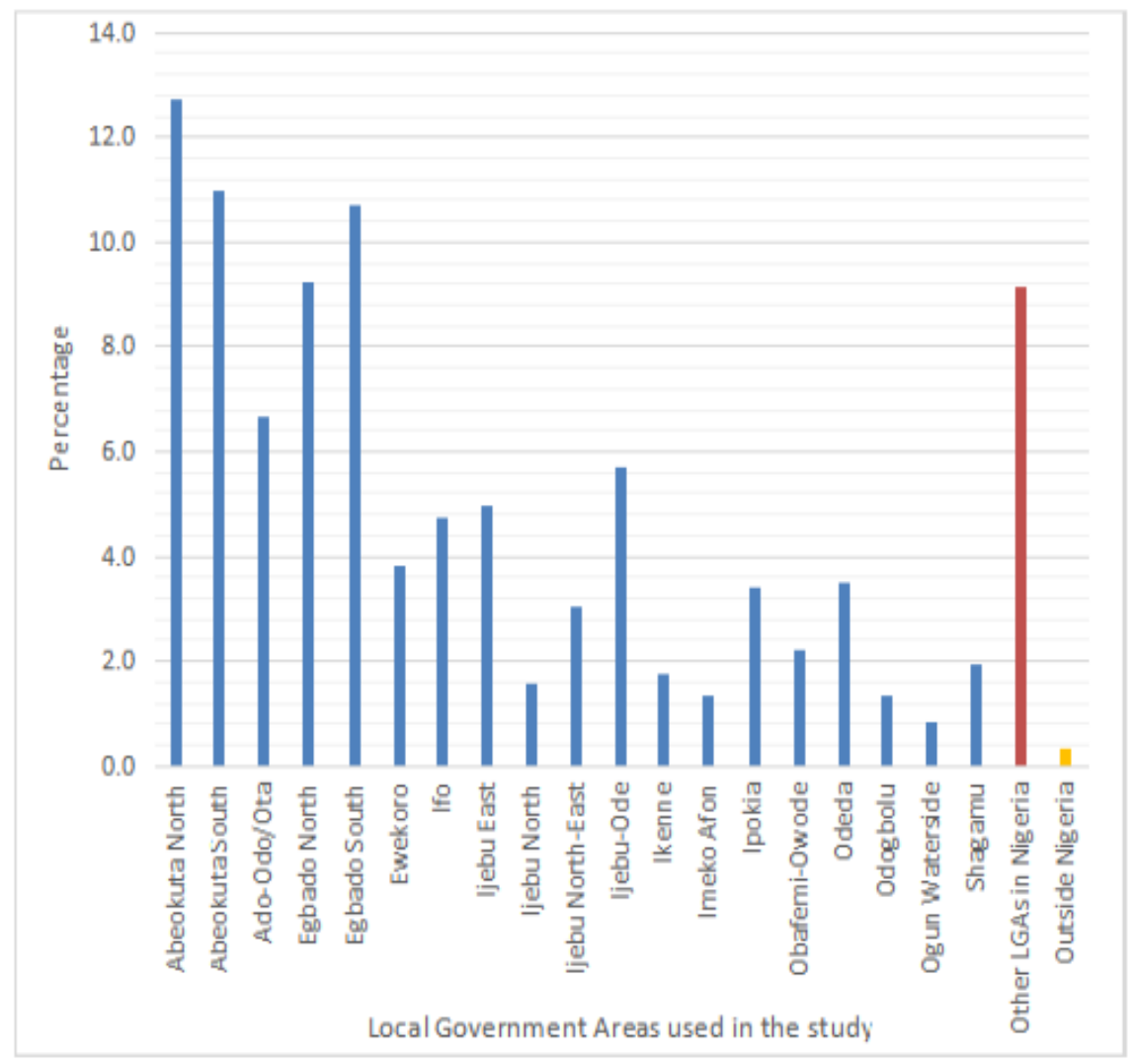

Figure 5. Local Government Areas used in the Study 


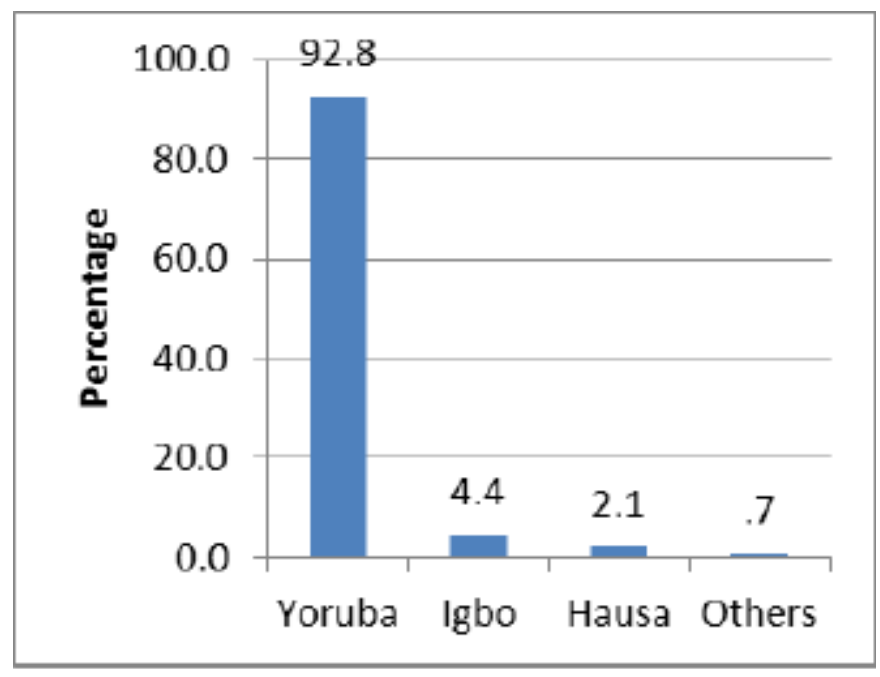

Figure 6. Ethnic Groups' Distribution of the Respondents

\section{Time and other Costs during the Lockdown}

During the lockdown, 1198 (50.7\%) of the respondents spent no time to and fro of the market or the place of work, while $17.9 \%$ and $19.3 \%$ of the respondents spent $1-2$ hours and 3-5 hours respectively (Figure. 7). In Figure 8, the least percentage $(7.2 \%)$ of the respondents showed that there was a percentage increment in the prices of consumable goods ranged between 101 and $300 \%$. The majority, 812 $(34.3 \%)$ of the respondents indicated that the prices of consumables increased between 21 and $40 \%$ (Figure. 8). Figure. 9 shows that $81.1 \%$ which represents 1913 respondents revealed that the cost of living during the lockdown was not suitable. Figure. 10 shows that a larger percentage (71.8\%) which represents 1697 of the total respondents indicated that the government did not provide palliative measures for the households. Table 2 presents the results of the extra profit and loss got by the respondents during the lockdown.

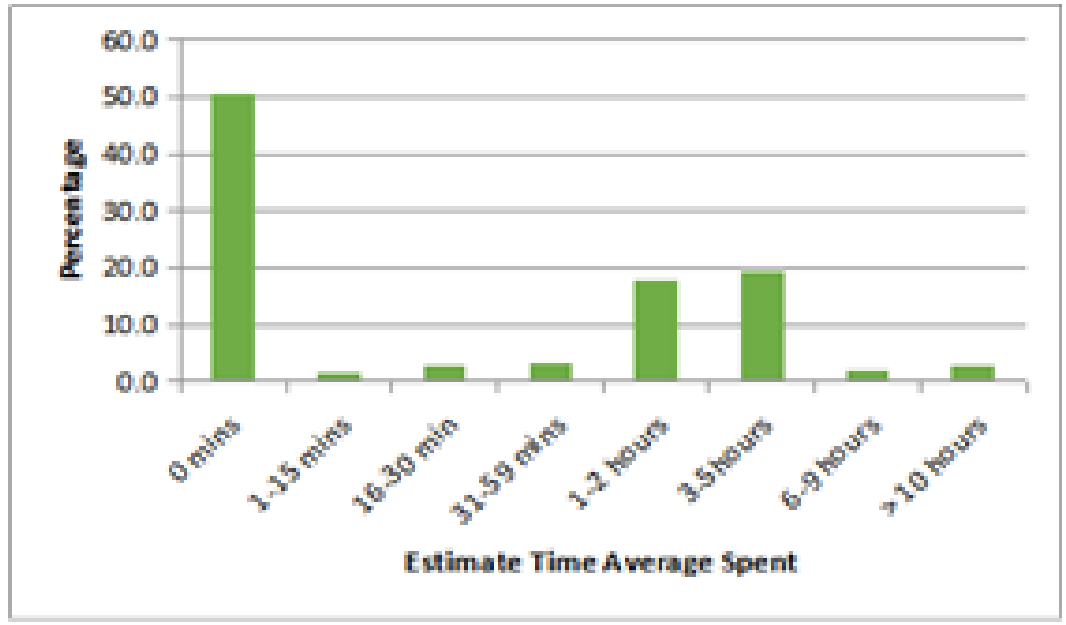

Figure 7. Estimated Time Average Spent to and Fro during the Lockdown 


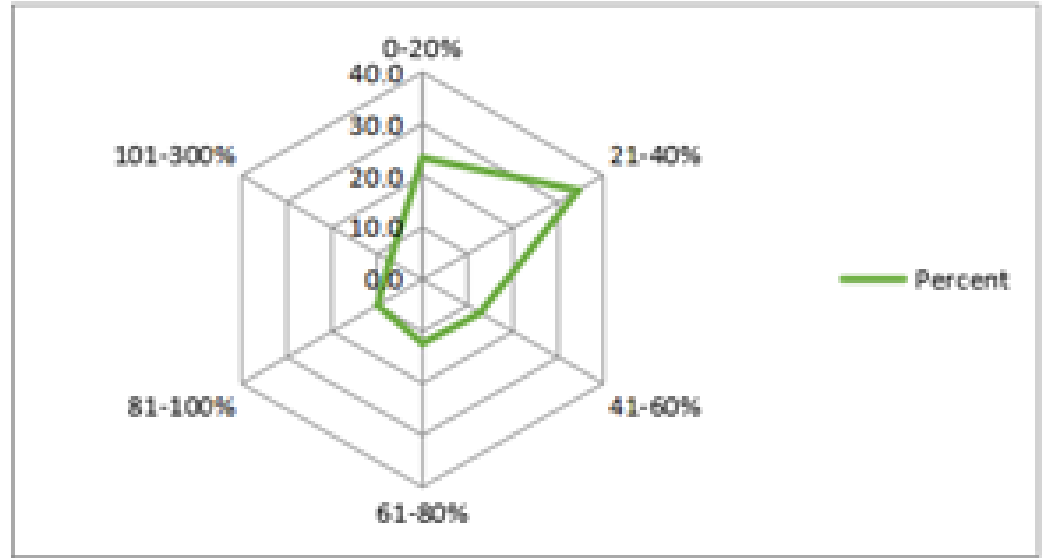

Figure 8. Percentage of Increments in Price of Consumables during the Lockdown

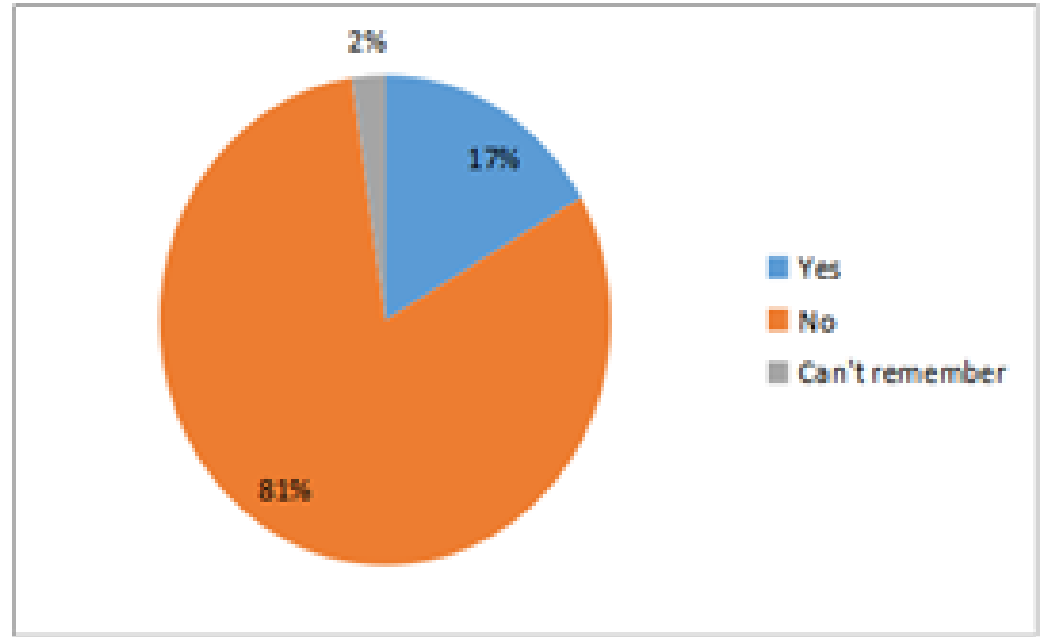

Figure 9. Suitability of Cost of Living During Lockdown

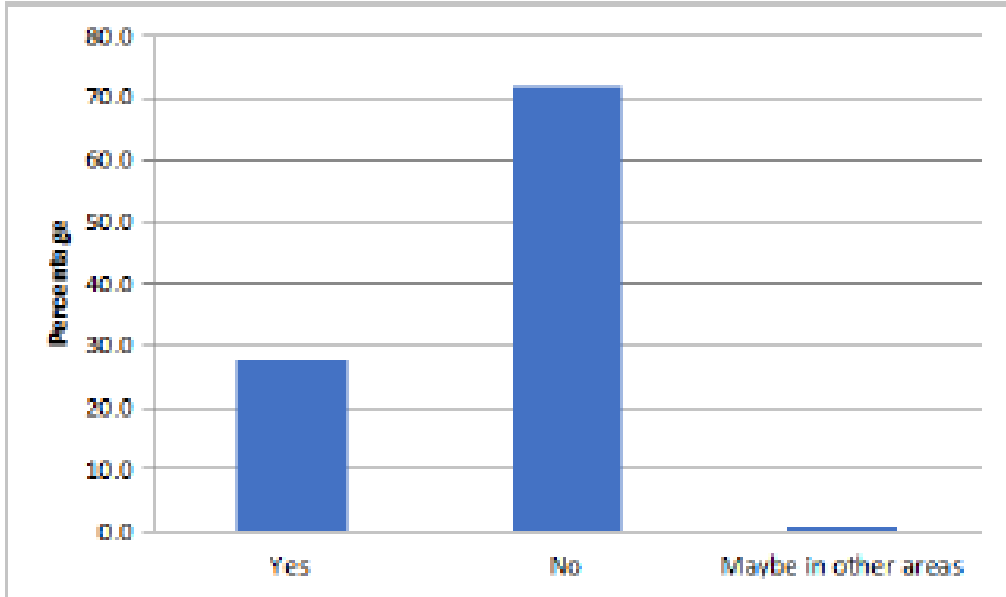

Figure 10. Palliative Measure by the Government

Table 2. Extra Income/Loss got during the Lockdown

\begin{tabular}{|l|l|l|l|}
\hline \multicolumn{2}{|c|}{} & Frequency & Percent \\
\hline \multirow{3}{*}{ Profit/Loss } & Yes & 428 & 18.1 \\
\cline { 2 - 4 } & No & 1935 & 81.9 \\
\cline { 2 - 4 } & Total & 2363 & 100.0 \\
\hline
\end{tabular}




\section{Health Belief Model (HBM) of COVID- 19 Pandemic}

\section{Perceived Susceptibility}

In table 3 , respondents clearly showed that $2031(86.0 \%)$ can be infected with COVID-19 including pastors, imams, and traditionalists while $1628(68.9 \%)$ of respondents were not at risk of COVID-19. $31.1 \%$ of the respondents stated that they were at risk of COVID-19. The majority of 1145 (48.5\%) of respondents showed that people can have COVID-19 without feeling its signs and symptoms. 1689 $(71.5 \%)$ of respondents revealed that COVID19 is not a curse from God and the majority $1689(71.5 \%)$ of respondents showed that COVID-19 is not handwork of evils-doers.

Table 3. Perceived Susceptibility

\begin{tabular}{|l|l|l|l|}
\hline Demographic Characteristics & Yes & No & \multirow{2}{*}{ Don't know } \\
\hline $\begin{array}{l}\text { Everybody can get COVID-19 } \\
\text { including pastors, imams and } \\
\text { traditionalists }\end{array}$ & 2031 & 332 & \multirow{2}{*}{-} \\
\cline { 2 - 4 } & $(86.0 \%)$ & $(14 \%)$ & \\
\hline Risk of COVID-19 & 735 & 1628 & - \\
\cline { 2 - 4 } & $(31.1 \%)$ & $(68.9 \%)$ & \\
\hline $\begin{array}{l}\text { People can have COVID-19 without } \\
\text { feeling its signs and symptoms }\end{array}$ & 1145 & 799 & 419 \\
\cline { 2 - 3 } & $(48.5 \%)$ & $(33.8 \%)$ & \multirow{2}{*}{$17.7 \%)$} \\
\hline COVID-19 is a curse from God & 674 & 1689 & \multirow{2}{*}{-} \\
\cline { 2 - 4 } & $(28.5 \%)$ & $(71.5 \%)$ & \\
\hline \multirow{2}{*}{$\begin{array}{l}\text { COVID-19 is a handwork of evils- } \\
\text { doers }\end{array}$} & 999 & 1364 & - \\
\cline { 2 - 3 } & $(42.3 \%)$ & $(57.7 \%)$ & \\
\hline
\end{tabular}

\section{Perceived Severity}

Figure. 11 shows that $52 \%$ of the respondents stated that COVID-19 drugs were available, while $48 \%$ revealed that COVID-19 drugs were unavailable. The responses of respondents that indicated that COVID-19 drugs are available might be medicinal herbs used to cure coldrelated illness. It was shown that COVID-19 is can lead to death as a larger percentage (84.1\%) of respondents indicated that COVID-19 could lead to death (Figure.12). A large number of the respondents constituting $1149(48.6 \%)$ revealed that prayers from religious leaders can not only cure COVID-19, while $21.8 \%$ of the respondents showed that the prayers from religious leaders may cure COVID-19 (Figure. 13).

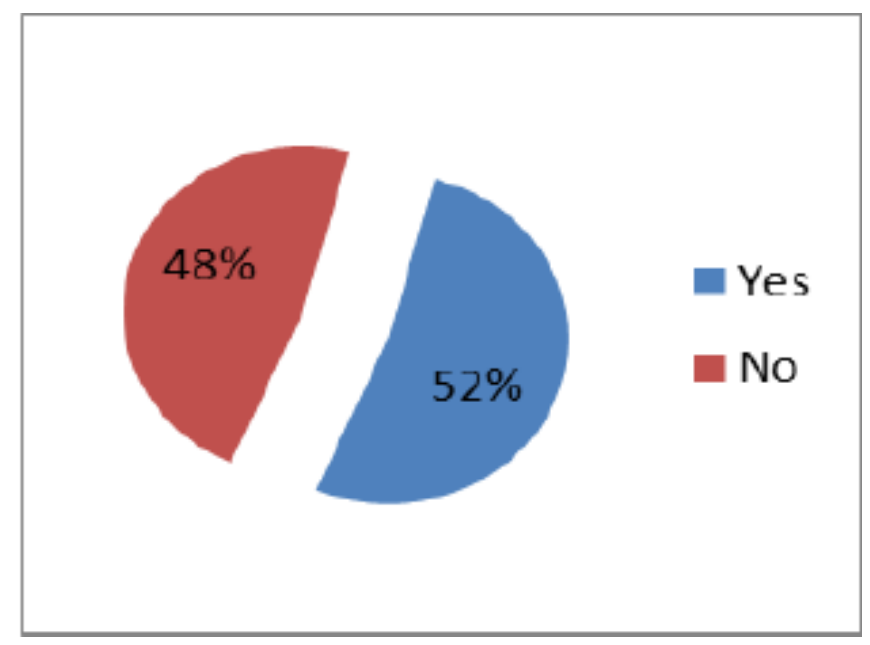

Figure 11. Availability of COVID-19 Drug 


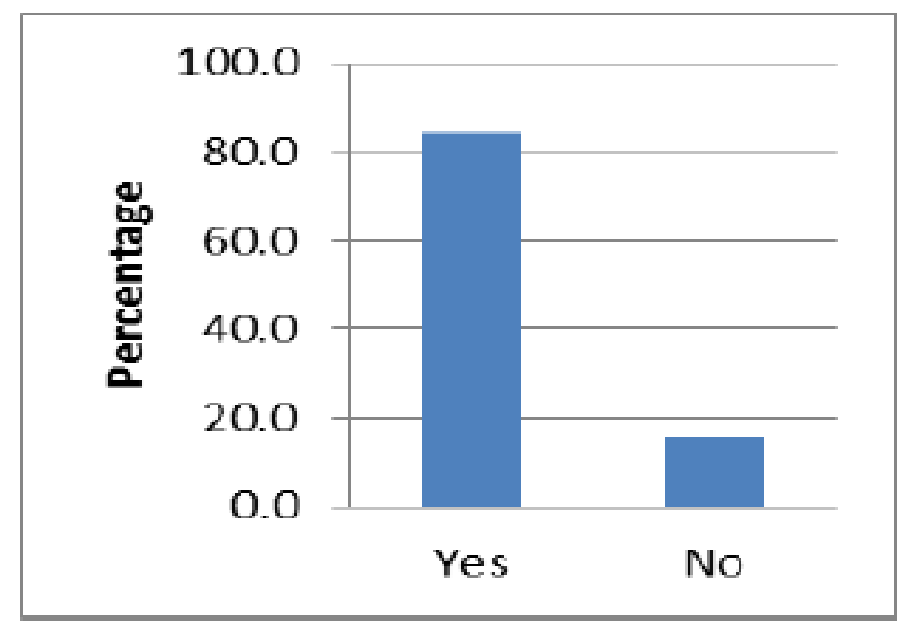

Figure 12. Death as an End Result of COVID-19

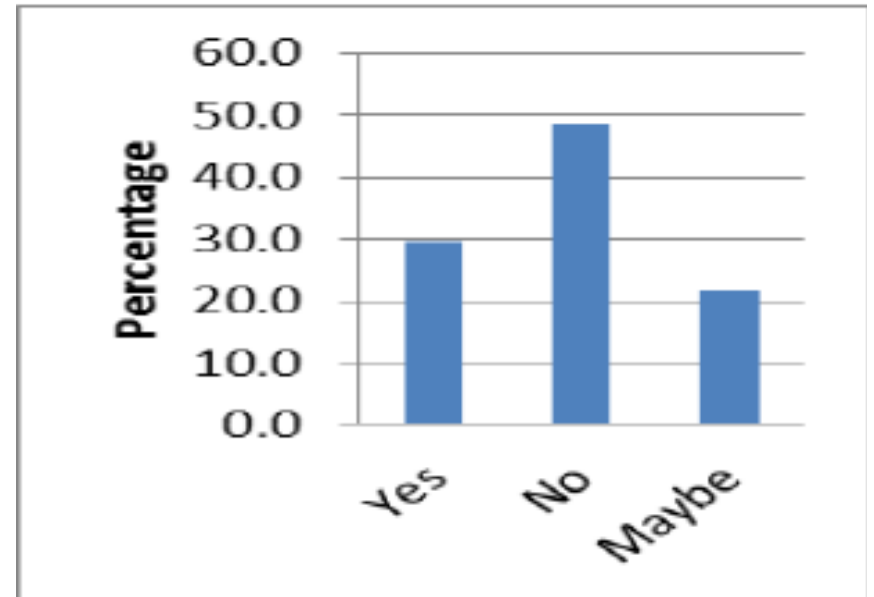

Figure 13. Prayers from Religious Leaders as Cure of COVID-19

\section{Perceived benefits}

In table 4 , it is shown that the three basic measures to prevent the spread of COVID-19 were largely shown by respondents in the study area. $1823(77.1 \%)$ of respondents showed that avoidance of social gathering can prevent the spread of COVID-19, 1993 (84.3\%) of respondents believed in regular hand washing as a measure to prevent the spread of COVID19 , while only 486 (20.6\%) of respondents believed that use of face mask cannot prevent a person from having COVID-19.

Table 4. Perceived Benefits

\begin{tabular}{|l|l|l|l|}
\hline Demographic Characteristics & Yes & No & Don't know \\
\hline $\begin{array}{l}\text { Avoidance of social gathering can } \\
\text { prevent the spread of COVID-19 }\end{array}$ & 1823 & 292 & 248 \\
\cline { 2 - 3 } & $(77.1 \%)$ & $(12.4 \%)$ & $(10.5 \%)$ \\
\hline $\begin{array}{l}\text { Believe in regular hand washing as a } \\
\text { preventive measure to the spread of } \\
\text { COVID-19 }\end{array}$ & 1993 & 370 & - \\
\cline { 2 - 3 } & $(84.3 \%)$ & $(15.7 \%)$ & \\
\hline $\begin{array}{l}\text { The use of a face mask can prevent a } \\
\text { person from having COVID-19 }\end{array}$ & 1877 & 486 & - \\
\cline { 2 - 3 } & $(79.4 \%)$ & $(20.6 \%)$ & \\
\hline
\end{tabular}




\section{Perceived barriers and self-efficacy}

In Figure. 14, 64\% of the respondents preferred going to Churches and/or Mosques to use face masks, while $42 \%$ which represents 993 of the respondents did not have time to use face masks during COVID-19 (Figure. 15). Only $58 \%$ had time to use a face mask or shield. Figure 16 presents how convenient was the face mask or shield to the daily activities of the respondents during COVID-19. The larger percentage of the respondents $(72.4 \%)$ which represents a total of 1710 of the targeted population was not convenient with the use of face masks while a small proportion (3.6\%) of the respondents found it very convenient during COVID-19 (Figure. 16). For not allowing social gatherings during COVID-19, a total of 1165 (49.3\%) of the respondents felt bad for not attending or gathering for social gatherings during COVID-19 (Table 5). In Figure. 17, $79.3 \%$ of the respondents were not satisfied to go to clubbing whenever they felt stressed out or bored during COVID-19.

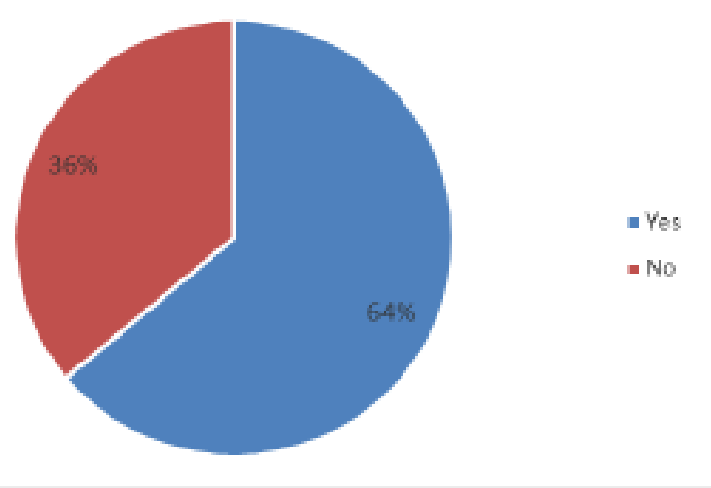

Figure 14. Preference to go to Churches and Mosque instead of using Face Masks

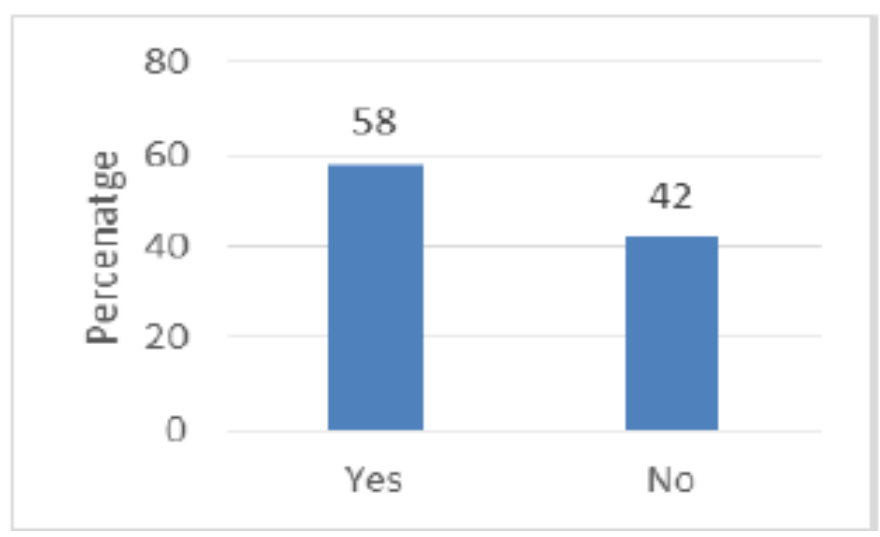

Figure 15. Time to use Face Mask

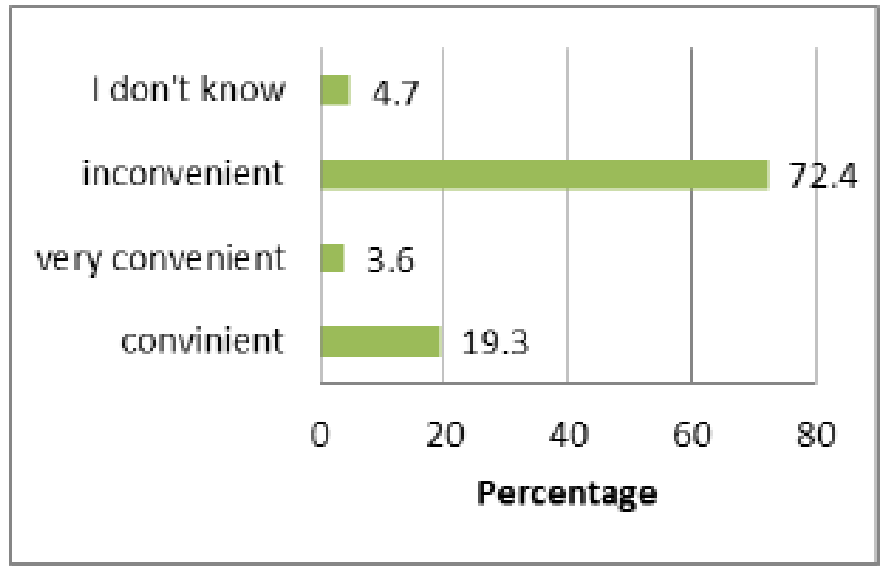

Figure 16. Inconvenience of the use of Face Masks or Shield to Daily Activities 
Table 5. How the Respondents Feel about not Going to a Social Gathering

\begin{tabular}{|l|l|l|}
\hline $\begin{array}{l}\text { Demographic } \\
\text { Characteristics }\end{array}$ & Yes & No \\
\hline Good & 399 & $16.9 \%$ \\
\hline Bad & 1165 & $49.3 \%$ \\
\hline Sick & 141 & $6 \%$ \\
\hline Nothing & 2363 & 27.8 \\
\hline
\end{tabular}

\section{Discussion}

Findings obtained from this study revealed the larger percentage of Nigerians in the study since the study area was conducted in Nigeria, while only a few respondents were nonNigerian. As the percentages of males and females varied in the study area, the ratio of male to female was 0.54 to 0.46 . A decrease in the percentage of aged people sampled in the study area could result in the age group of people who were easily affected by COVID-19. This made aged people not to be involved in this study.

Considering the gender of the respondents in the study area, the little variation in the percentages of the marital status of the respondents might be the large number of students involved in this study. The results of the education levels of the respondents showed an indication that the majority of the people in the study are educated with a very small number of people without formal education. In terms of the occupational activities of people in the study area, the majority of them were still in school, while teachers and other professions constitute larger percentages of the respondents. A very small number of the respondents $(0.3 \%)$ belonged to none of the three major religions, and this justifies that the respondents worshiped nothing. The results of this study showed that Islam and Christianity are the most common religions in the study area.

The larger percentage $(50.7 \%)$ of the respondents that spent no time to and fro to the market or place of work showed that the majority of the respondents did not go anywhere during the lockdown as they were restricted during this period. Considering the responses of respondents on the percentage increment in the prices of consumables, it is shown that the prices of consumables were inflated, which might be associated with low supply or production of consumables during the lockdown. This made the cost of living unsuitable and many people suffered during the lockdown. An indication of the large percentage $(81.1 \%)$ of the respondents of the high cost of living during the lockdown was affected as they adapted to the pandemic's situation.

This study found that COVID-19 poses a significant threat to the local economy, resulting in low income and resultant hunger. This is likely due to the increased cost of purchasing goods or a result of the lockdown, which has denied many individuals the opportunity to earn their income. Denial of opportunities to engage in money-making ventures was experienced and impacts such as hunger were greatly felt among many persons [19]. This explains the need for the provision of palliatives to fight hunger and reduce susceptibility to other infections during the COVID-19 outbreak. Non-provision of palliative measures for the citizens by the government might be attributed to inadequate resources to do so. While many state governments in the country hoard the palliatives which were meant for the citizens, only a few state governments were able to provide the palliative measures for their people in the country. As it affects, the economic activities of the people in the study area, as many respondents could not make an extra profit during the lockdown, this could be attributed to the restriction of people and other commercial activities to take place during the lockdown.

Similarly, decreased productivity and job losses and an unprecedented economic disaster have been reported [20]. Contrary to the finding in this study, other studies have reported stress and anxiety as psychological reactions due to the Coronavirus pandemic [20]. Other psychological reactions such as boredom, anger, and loneliness have been notably identified as resultant threats during the COVID-19 pandemic [21]. This calls for the provision of psychosocial support for individuals during the COVID-19 lockdown. 
Considering the kind of people that can be infected with COVID-19, the result of the larger percentage of respondents indicated that pastors, imams, and traditionalists could be infected with COVID-19. These results signify that everyone was at risk of COVID-19. The small percentage of respondents that showed that they were at risk of COVID-19, might be because COVID-19 is easily spread; old age; traveling from one place to another; nature of their work (health workers); and unknown infected persons to mention but a few. This result corresponds to the study of [22] which reported that a small percentage $(26 \%)$ of the respondents was at risk of COVID-19 in Ibadan, Nigeria.

Education is a very important thing in this study as the level of education of the respondents in the study area enabled individuals to believe that COVID-19 is not a curse from God and also is not the handwork of the devil, as the majority believed. Though, education has nothing to do with health beliefs because $21.8 \%$ of the respondents in the study area indicated that the prayers from religious leaders might cure COVID-19. It is unimaginable when an individual with a good education vehemently opposes seeking health interventionism when an outbreak of (e.g. COVID-19) occurs. This is due to his/her belief that prayers work better than any control of the disease. There are billions of people throughout the world who believe prayers and spirituality are just as vital for healing as modern medicine is, as religious practices and beliefs have consistently been a source of medical treatment for ages [23]. Beliefs such as these may serve to provide a sense of well-being in the face of health difficulties, growing out of the comfort of feeling that one's fate is under the control of a benevolent being. Religious denominations may prescribe lifestyles that promote health.

From the present study, a high rating of the perceived likelihood of contracting COVID-19 was observed among the respondents, while it was maximally perceived as an attack by the Western World. This means that COVID-19 was not a curse from God and not the handwork of the devil. As the majority of the respondents believed that paying attention and/or utilization of the basic measures put in place to curb the spread of COVID-19, only 486 (20.6\%) of respondents believed that use of a face mask cannot prevent a person from having COVID19. This could be a challenge in using face masks to curb the spread of COVID-19. This result corresponds to the study conducted by [22] as the use of face masks and social distancing were the most frequently reported practices for the prevention of COVID-19.

The results of this study showed that $64 \%$ of the respondents preferred going to Churches and/or Mosques to use face masks. This showed that respondents were not comfortable and convenient in using face masks in the study area. A greater proportion $(65.5 \%)$ of the respondents were able to follow the basic measures put in place to reduce the spread of CVOID-19 in the study area The results obtained herein are higher than the knowledge concerning the practice of face masks in Saudi Arabia [24]. Due to its deadly nature, COVID19 has introduced fear which has compelled protective actions from individuals, especially during an epidemic, but such behaviour may not be sustainable $[25,26]$. The adoption of these healthy behaviours in this study is in tandem with the recommendations of the World Health Organisation (WHO) on safety measures for COVID-19 (WHO, 2020).

Another basic measure put in place to curb the spread of COVID-19 which is handwashing is an important measure the respondents also adopted to curb the spread of COVID-19 in the study area. Lassa fever studies conducted in Edo State reported inadequate handwashing as one of the basic practices, while a similar study in Kaduna State, Nigeria, reported good handwashing practices among respondents [27]. The similarities of most of these findings with ours imply the wide acceptance of the practice of basic practices in the management of infectious diseases.

\section{Conclusion}

This study has examined the cost-benefit analysis during the lockdown of COVID-19 and the health belief model of COVID-19 pandemic in Ogun State, Nigeria, as it brought an unprecedented threat to the economy and the quality of life. Results showed that the majority $(50.7 \%)$ of the respondents spent no time to go to the market and/or work during COVID-19 and $81.9 \%$ of them unable to gain extra gain during the lockdown in the study area. The 
findings of this study also revealed that the lockdown had impacts on the socio-economic activities of the people. Respondents also indicated that the government in the study area did not make palliative measures for the households. At this present time, no COVID-19 drugs are available and prayers alone from religious leaders could not only cure it. This study has revealed that the COVID-19 pandemic caused an unprecedented threat to the economy and the quality of life. This study recommends that health education campaigns concerning COVID-19 should be conducted by public health officials in simple, unambiguous

\section{References}

[1] Gallegos, A., 2020, WHO declares public health emergency for novel coronavirus. Medscape Medical News. Accessed: 30/01/2020. https://www.medscape.com/viewarticle/924 596.

[2] Ramzy, A., and McNeil, D.G., 2020, W.H.O. declare global emergency as Wuhan coronavirus spreads. The New York Times. Accessed: 30/01/2020. https://nyti.ms/2RER70M.

[3] The New York Times, 2020, Nigeria Responds to First Coronavirus Case in Sub-Saharan Africa. 28 March 2020.

[4] Centers for Disease Control and Prevention, 2020, How COVID-19 Spreads. Accessed: 04/03/2020

https://www.cdc.gov/coronavirus/2019ncov/prepare/ transmission.html?CDC_AA_refVal=https $\% 3 \mathrm{~A} \% 2 \mathrm{~F}$ \%2Fwww.cdc.gov\%2Fcoronavirus\%2F2019ncov\%2 Fabout\%2Ftransmission.html

[5] Scherbina, B., 2020, Determining the optimal duration of the COVID-19 suppression policy: A cost-benefit analysis. AEI Economics Working Paper 2020-03. American Enterprise Institute, 1-28.

[6] Abraham, C., and Sheeran, P., 2015, The health belief model. In: Predicting and changing health behaviour: Research and Practice with Social Cognition Models, edited by Mark, C., and Paul, N., Third edition (New York, USA: Mark Conner and Paul Norman), pp. 30-69.

[7] Kirscht, J.P., 1983, Preventive health behaviour: A review of research and issues. Health Psychology, 2, 277-301.

[8] Murphy, S.A., 2006, Consumer health information for pet owners. Journal of the Medical Library Association, 94(2), 152-158. languages which will facilitate the understanding of community members. Also, the availability of medical supplies and palliatives would enhance the adherence to safety measures for COVID-19, such as the use of face masks among community members.

\section{Acknowledgment}

The author is grateful to acknowledge those that have helped in one way or the other to the successful completion of this study. I appreciate Salami Afeez Alabi for his immense contribution to the drafting and adjustment of this paper.

[9] Glanz, K., Rimer, B., and Viswanath, K., 2008, Health behavior and health education: Theory, research, and practice. 4th edition (San Francisco: Jossey-Bass).

[10]Lewin, K., 1936, Principles of topological psychology (New York: McGraw-Hill).

[11]Lewin, K.A., 1935, Dynamic theory of personality (New York: McGraw-Hill).

[12] Hochbaum, G.M., 1958, Public participation in medical screening programs: A socio-psychological study. Public health service publication, 572. Washington, DC: US Government Printing Office.

[13] Rosenstock, I.M., 1966, Why people use health services. Milbank Memorial Fund Quarterly, 44, 94-124.

[14]Boskey, E., 2019, Health Belief Model: Use of a condom may hinge on your perceived risk of STDs. Accessed: 20/04/2020.

[15] Kegeles, S.S., 1963, Why people seek dental care. Journal of Health and Human Behavior, 7, 242-254.

[16] National Population Commission, 2006, Federal Republic of Nigeria 2006 Population and Housing Census, Priority Tables, Vol. VII Abuja, Nigeria.

[17] Ogun State Population (2020). Population of Ogun State. Accessed: 16/04/2020. http://population.city/nigeria/adm/ogun/.

[18] Sample Size (2020). Online Sample Size Calculator. Accessed 15/05/2020. http://www.raosoft.com/samplesize.html.

[19] Chukwuorji J.C., Iorfa, S.K., 2020, Commentary on the coronavirus pandemic: Nigeria. Psychological Trauma: Theory, Research, Practice, and Policy, 12(S1), S188-S190 DOI $10.1037 /$ tra0000786.

[20] Atalan, A., 2020, Is the lockdown important to prevent the COVID-9 pandemic? Effects on 
psychology, environment, and economy-perspective. Annals of Medicine and Surgery, 56:38-42. DOI 10.1016/j.amsu.2020.06.010.

[21] Aluh, D.O., Onu, J.U., 2020, The need for psychosocial support amid COVID-19 crises in Nigeria. Epub ahead of print 22 June 2020. Psychological Trauma: Theory, Research, Practice, and Policy. DOI 10.1037/tra0000704.

[22] Ilesanmi, O., Afolabi, A., 2020, Perception and practices during the COVID-19 pandemic in an urban community in Nigeria: A cross-sectional study. PeerJ 8:e10038 DOI 10.7717/peerj.10038.

[23] Mishra, S.K., Togneri, E., Tripathi, B., and Trikamji, B., 2015, Spirituality and religiosity and its role in health and diseases. Journal of Religion and Health. Springer. DOI: 10.1007/s10943-0150100-z.

[24] Al-Hanawi, M.K., Angawi, K., Alshareef, N., Qattan, A.M.N., Helmy, H.Z., Abudawood, Y., Alqurashi, M., Kattan, W.M., Kadasah, N.A., Chirwa, G.C., Alsharqi, O., 2020, Knowledge, attitude and practice toward COVID-19 among the public in the Kingdom of Saudi Arabia: A cross- sectional study. Frontiers in Public Health 8, 1-9 DOI 10.3389/fpubh.2020.00217.

[25] Witte, K., 1998, Fear as motivator, fear as inhibitor: Using the extended parallel process model [26] to explain fear appeal successes and failures. In: The Handbook of Communication and Emotion: Research, Theory, Applications, and Contexts edited by Andersen, P.A., Guerrero, L.K., (San Diego: Academic), 423-450.

[27] Ufuwa, I.S., Akpa, C.O., Umeokonkwo, C.D., Umoke, M., Oguanuo, C.S., Olorukooba, A.A., Bamgboye, E., Balogun, M.S., 2020, Knowledge and risk perception towards Lassa fever infection among residents of affected communities in Ebonyi State, Nigeria: Implications for risk communication. BMC Public Health, 20(1),1-10 DOI 10.1186/s12889-020-8299-3.

[28] Tobin, E.A., Asogun, D.A., Isah, E.C., Ugege, O.G., Ebhodaghe, P., 2013, Knowledge and practice of infection control among primary care providers in an endemic suburban community of Edo State: Implications for control. Journal of Medicine and Medical Sciences, 4:311-318. 